\title{
SISTEMA INQUISITORIAL E A INFLUÊNCIA NA FORMAÇÃO DA CRIMINOLOGIA POSITIVISTA NO BRASIL
}

\author{
INQUISITORIAL SYSTEM AND THE INFLUENCE ON THE FORMATION \\ OF THE POSITIVIST CRIMINOLOGY IN BRAZIL
}

\author{
SISTEMA INQUISITORIAL Y SU INFLUENCIA EN LA FORMACIÓN \\ DE LA CRIMINOLOGÍA POSITIVISTA EN BRASIL
}

Fernanda Martins

Carlos Alberto Luiz Gonçalvez

\begin{abstract}
Resumo: O presente trabalho visa traçar um perpasso histórico sobre a construção do Sistema Inquisitorial como uma forma processual, cuja influência alcançou a América e a produção intelecutal brasileira, através da inserção da Criminologia Positivista. Visa-se também demonstrar como a política excludente e preconceituosa do processualismo inquisitorial na sua formação medieval determinou para o desenvolvimento da atualmente conhecida Criminologia Lombrosiana. É válido também determinar que o presente artigo aborda a postura do juiz inquisidor como uma marco teórico para a construção da figura dos magistrados atuais nos termos do processo penal brasileiro em plenos século XXI.
\end{abstract}

Palavras-chave: Inquisição. Criminologia positivista. Juiz inquisidor.

\begin{abstract}
This paper aims to outline the history of the Inquisitorial System 's construction as a procedural way, whose influence reached America and the brazilian's intellectual production, through the insertion of Positivist Criminology. It aims also demonstrate how prejudiced and exclusionary politics of processualism medieval inquisitorial in its formation has determined the development of the currently known Lombrosian Criminology. It is also valid to expose that this article discusses the position of inquisitor judge as a theoretical framework for the construction of the current judges in terms of criminal right in Brazil on the XXI century.
\end{abstract}

Keywords: Inquisition. Positivist criminology. Inquisitor judge

Resumen: Este artículo pretende esbozar la historia de la construcción del sistema inquisitivo como una forma de procedimiento, cuya influencia llegó a América y a producción brasileña intelectual, a través de la inserción de criminología positivista. Visa también demonstrar cómo la política de prejuicios y exclusión de procesualismo inquisitorial medieval en su formación ha determinado el desarrollo de la criminología lombrosiana conocida actualmente. También es válida la determinación que este artículo se describe sobre la posición de juez inquisidor como marco teórico para la construcción de la figura de los jueces actuales en términos del derecho penal e procesal brasileño del siglo XXI.

Palabras clave: Inquisición. La criminología positivista. Juez inquisidor.

\section{INTRODUÇÃO}

O presente artigo propõe identificar a expressão "juiz inquisidor" a partir da sua construção histórica, abordando-se uma construção conceitual pautada, sobretudo, na História do Direito, a qual identificará sobre o que se tratava o processo inquisitorial no contexto da sua existência, ou seja, no período medieval.

Após uma conceitualização abrangente no tocante ao sistema inquisitorial como forma processual, identificar-se-á a inserção no Brasil deste método de desenvolver o processo, a partir das visitações da Inquisição às Colônias portuguesas, trabalhando-se ainda com os porquês de terem sido necessárias tais intervenções católicas no Brasil.
Será também demonstrado o surgimento da criminologia como resposta a esta forma processual, já que os primeiros estudos criminológicos focavam-se na segregação e identificação do outro como meio de constituir uma razão ao problema da criminalidade.

O presente estudo finalizar-se-á, então, com a explanação sobre a função do juiz inquisidor e sobre os atos por este praticados como inerentes a essa titulação.

O Processo Penal e o Direito Penal na forma que se conhece atualmente são resultados de um processo histórico, cuja influência é proveniente de diversos movimentos jurídicos ocorridos ao longo dos séculos na parte Ocidental do mundo. Entre eles pode-se citar a Retórica grega, o Direito Germânico regido pelo jogo

\footnotetext{
*Artigo recebido em agosto de 2013

Aprovado em outubro de 2013
} 
de prova, o Inquérito grego, a renovação do Inquérito medieval, a reforma Iluminista de se pensar o Direito e o desenvolvimento do sistema liberal jurídico (FOUCAULT, 2003, p. 53 - 78).

Abordar-se-á aqui o Inquérito medieval como fonte de análise para se entender o Sistema Inquisitorial, o qual começa a se consagrar a partir da Alta Idade Média, e cuja formação provém de um movimento modificador dos costumes, de consciência e do processo judiciário em si durante o medievo, como também será objeto de análise o processo histórico que permeou a construção deste Sistema.

\section{A FORMAÇÃO DO SISTEMA INQUISITORIAL COMO FORMAÇÃO DE SISTEMA PROCESSUAL}

Foucault (2003, p. 64) identifica que "guerra, litígio judiciário e circulação de bens fazem parte, ao longo da Idade Média, de um grande processo único e flutuante". O que se compreende no sentido que durante este período começam a se formar poderes constituídos que passam a serem agregados nos mesmos indivíduos. Trata-se de mudança significativa, pois se falava da Baixa Idade Média como uma sociedade que até então possuía diversos pólos de poder dispersos, o que caracterizava o momento chamado de Feudalismo.

Para que a constituição desta nova perspectiva de poder se acumulasse definitivamente nas mãos de uns poucos, o processo judiciário foi determinante. que:

É evidenciado por Foucault (2003, p. 65)

a acumulação da riqueza e do poder das armas e a constituição do poder judiciário nas mãos de alguns é um mesmo processo que vigorou na Alta Idade Media e alcançou seu amadurecimento no momento da formação da primeira grande monarquia medieval, no meio ou final do século XII.

$E$ é diante deste momento que se desenvolve uma justiça completamente distinta da até então evidenciada durante o período feudal e das épocas antecedentes.

A autora Samyra Haydée Naspolini Sanches (2003), ao traçar historicamente o surgimento e o desenvolvimento do Sistema Inquisitorial, identifica que durante a Baixa Idade Média o poder clerical vigia sobre toda a sociedade ocidental e que o poder da nobreza estava diretamente vinculado com a aceitação do Clero sobre a figura dos "novos" reis, podendo o poder clerical consagrar ou excomungar um nobre, como desejasse (SANCHES, 2010, p. 241).

O início da Inquisição se deu na Baixa Idade Média e o foco deste procedimento estava voltado para o combate das heresias, ou seja, das práticas que contestavam os dogmas católicos (SANCHES, 2010, p. 241). Para que se concluísse se havia sido ou não praticadas condutas hereges deveria ocorrer um processo, no qual a peça chave era o Inquérito.

O Inquérito teve seu processo de "recriação" a partir do século XII, quando em momentos de conflitos "os representantes do soberano tinham de solucionar um problema de direito, de poder, ou uma questão de impostos, de costumes, de foro ou de propriedade" (FOUCAULT, 2003, p. 68) e buscavam em "algo perfeitamente ritualizado e regular", o que era chamado de "inquisitio, o Inquérito" (FOUCAULT, 2003, p. 68). O Inquérito veio com a proposta de ser um método jurídico para a obtenção da verdade, o qual foi classificado como um processo de dupla origem, uma com base na forma administrativa e outra na forma religiosa.

A forma administrativa consistia num questionamento aos "notáveis", pessoas de conhecimento notório e de reputação ilibada, sobre os fatos controversos, cujo objetivo era sempre a obtenção da "verdade real". Tal forma de inquérito estava ligada ao surgimento do Estado e ao exercício do poder em si. No entanto, a outra forma, a eclesiástica, consistia num Inquérito vinculado aos dogmas clericais, e neste método buscava-se também a dita "verdade real", todavia o foco era a ocorrência de crimes religiosos e/ou heresias (FOUCAULT, 2003, p. $68-71$ ).

O Inquérito é por Aury Lopes Júnior, no tocante a sua forma religiosa, dividido em duas fases: "a primeira fase (geral) estava destinada à comprovação da autoria e da materialidade, e tinha um caráter de investigação preliminar e preparatória com relação à segunda (especial), que se ocupava do processamento (condenação e castigo)" (LOPES Jr., 2006, p. 168).

As novas regras e novos personagens dessa "nova justiça" que vem a se formar no período medieval são indicados por Foucault (2003, p. 65-67) como os seguintes:

1. Uma justiça que não é mais contestação entre indivíduos e a livre aceitação por esses indivíduos de um certo número de regras de liquidação, mas que, ao contrário, vai-se impor, do alto, aos indivíduos, aos oponentes, aos partidos. [...] Os indivíduos então não terão mais o direito de resolver, regular ou irregularmente, seus litígios; deverão submeter-se a um poder exterior a eles que se impõe como poder judiciário e poder político.

2. Aparece um personagem totalmente novo sem precedentes no Direito Romano: o procurador. Esse curioso personagem, que aparece na Europa por volta do século XII, vai se apresentar como o representante do soberano, do rei ou do senhor. Havendo crime, delito ou contestação entre dois indivíduos, ele se apresenta com representante de um poder lesado pelo único fato de ter havido um delito ou um crime. [...] O soberano, o poder político vêm, desta forma, dublar e, pouco a pouco, substituir a vítima. Esse fenômeno, absolutamente novo, vai permitir ao poder político apossar-se dos procedimentos judiciários. O procurador, portanto, se apresenta como representante do soberano lesado pelo dano. 
3. Uma noção absolutamente nova aparece: a infração. [...] A partir do momento em que o soberano ou seu representante, o procurador, dizem "Também fui lesado pelo dano", isto significa que o dano não é somente uma ofensa de um indivíduo ao outro, mas também uma ofensa de um indivíduo ao Estado; [...].

A infração não é um dano cometido por um indivíduo contra o outro; é uma ofensa ou lesão de um indivíduo à ordem, ao Estado, à lei, à sociedade, à soberania, ao soberano.

4. Há ainda uma última descoberta, uma última invenção tão diabólica quanto a do procurador e da infração: o Estado ou melhor, o soberano (já que não se pode falar de Estado nesta época) é não somente a parte lesada mas a que exige reparação. [...] Vai-se exigir do culpado não só a reparação do dano feito a um outro indivíduo, mas também a reparação da ofensa que cometeu contra o soberano, o Estado, a lei.

Esses novos mecanismos vão se tornar determinantes para a compreensão dos princípios que regerão o Sistema Inquisitorial e que determinarão o fortalecimento e a manutenção do poder nas mãos do Clero e da Nobreza, ao longo do medievo.

Salo de Carvalho atribui o surgimento do Sistema Inquisitorial na forma medieval e a sua afirmação como sistema válido e vigente neste período como resultado também da necessidade de "ampliação da malha repressiva" (CARVALHO, 2005, p. 39). Com base em Levack, o referido autor determina como processo histórico significante para a consolidação deste sistema a

"redescoberta" do Direito Romano, sobretudo com a revitalização do "Corpus Iuris Civilis" no século XII pela Universidade de Bolonha e a posterior inserção das glosas, o clero instiga a formalização e a mudança nos procedimentos - "a Igreja se aproveita do texto do corpus iuris civilis para escorar sua própria organização e desenvolver mecanicamente sua teocracia radical" (CARVALHO, 2005, p. 166 - 167).

Tal processo garantiu certas vantagens, no que entende o autor, dentre as quais se destacam:

(a) o caráter público das denúncias, não mais restritas à vítima ou aos seus familiares, aliada (b) ao sigilo da identidade do delator; (c) a inexistência de separação entre as figuras de acusador e julgador sendo lícito a este realizar a imputação, produzir a prova e julgar o acusado; (d) o sistema tarifado de provas e sua graduação na escala da culpabilidade, recebendo a confissão o máximo valor (regina probatio), e (e) a autorização irrestrita da tortura como mecanismo idôneo para obtenção de confissões. (CARVALHO, 2005, p. 37).

É diante destas vantagens que se começa a compreender o porquê da consolidação de tal estrutura e que se desenvolve o Sistema Processual Inquisitorial mais conhecido a partir da modernidade.

Aury Lopes Júnior ao identificar a institucionalização do Processo Inquisitorial como forma processual vigente, determina que tal consolidação é proveniente de um processo

de substituição dos defeitos da inatividade das partes, levando à conclusão de que a persecução crimi- nal não poderia ser deixada nas mãos dos particulares, pois isso comprometia seriamente a eficácia do combate à delinqüência. Era uma função que deveria assumir o Estado e que deveria ser exercida conforme os limites da legalidade (LOPES JÚNIOR, 2006, p. 166 - 167).

O Sistema Inquisitorial surge, a partir da compreensão de Coutinho, como "uma resposta defensiva contra o desenvolvimento daquilo que convencionou se chamar de 'doutrinas heréticas'.Trata-se, sem dúvida, do maior engenho jurídico que o mundo conheceu; e conhece" (COUTINHO, 2001, p. 18). Para Coutinho, tal sistema permaneceu vigente durante tanto tempo, e ainda vige, às vezes veladamente às vezes nem tanto, porque a Inquisição "veio com a finalidade específica e, porque serve - e continuará servindo, se não acordarmos - mantém-se hígido" (COUTINHO, 2001, p. 19).

O Sistema Inquisitorial era, e pode-se dizer que ainda é, instituído através de uma "máquina repressiva" (CARVALHO, 2005, p. 60), caracterizado pela "exclusão do contraditório, pela ausência de ampla defesa e pela inversão da presunção de inocência" (CARVALHO, 2005, p. 61).

O processo inquisitorial ou causa, como é chamada por Eymerico, poderia começar de três modos: "por acusação, por delação e por pesquisa" (EYMERICO, 2001, p. 16). O método da acusação se dava quando alguém do povo acusava o réu, sendo que nesta forma de causa deveria o delator provar o que afirmava sobre o acusado, e ele mesmo deveria ser o responsável pela persecução penal. Ou seja, o acusador enfrentaria o acusado pessoalmente e caso não provasse os fatos incursos ao réu, aquele quem acusara sofreria sanções severas (EYMERICO, 2001, p. 16).

Já no que se aborda a delação, o delator deveria contar ao juízo competente o motivo da acusação, mas não seria ele quem deveria provar tais alegações, e jamais seria este confrontado com o acusado, devendo o acusador de ofício ser responsável pelo trâmite processual (EYMERICO, 2001, p. 17).

Destarte, a terceira forma tratava-se da pesquisa, cuja utilização ocorria quando não havia nem delator, nem acusador. A pesquisa poderia ocorrer de duas maneiras:

uma geral, que é uma pesquisa de hereges que, de quando em quando, mandam fazer os inquisidores em um bispado ou em uma província. [...] A outra espécie de pesquisa se faz quando por voz pública chega aos ouvidos dos inquisidores que fulano ou sicrano disse ou fez alguma coisa contra fé, o que faz com que o inquisidor cite testemunhas e lhes tome declarações acerca da má fama do acusado (EYMERICO, 2001, p. 17 - 18).

Ambas as formas de pesquisa possibilitavam o início do processo de ofício pelo inquisidor.

Como base fundamental desta "forma processual", observa-se a "gestão da prova" (COUTINHO, 2001, p. 24) e a figura do juiz 
como acusador e julgador, objetos que serão tratados mais afundo quando for abordada a figura do juiz inquisidor. Todavia, no que trata desta perspectiva, vale ressaltar que a gestão probatória trazia valorações para as provas evidenciadas ao longo do "processo" e que o dinamismo processual ocorria sempre em virtude da busca da verdade.

As provas eram divididas entre "diretas, indiretas, manifestas, imperfeitas, provas plenas, indícios próximos e indícios longínquos" (SANCHES, 2010, p. 248). Para a autora Samyra Haydêe Naspolini Sanches as "provas plenas poderiam acarretar qualquer condenação, as semiplenas ensejar suplícios, mas nunca a pena capital, e os indícios bastavam para declarar um suspeito e iniciar as investigações" (SANCHES, 2010, p. 249). A combinação destas formas probatórias criava o que a mesma chama de "aritmética penal", devendo, entretanto, ao longo do processo sempre se buscar a confissão, já que esta era a única maneira de "provar" efetivamente que o indivíduo cometera crimes de heresias que não deixavam vestígios.

Para Alexandre Morais da Rosa (2006), entre as características do Sistema Inquisitorial se encontra a tarifação das provas e a acusação de ofício, como exposto, porém adiciona-se aos mesmos outros pontos fundantes deste sistema, tais como a presença de um único julgador, o poder de julgar, acusar e direcionar a ordem do processo nas mãos do magistrado e a realização de um processo escrito e secreto (ROSA, 2006, p. 135).

A perspectiva de Salo de Carvalho (2010), sobre as características de tal Sistema, permeia a mesma abordagem de Alexandre Morais da Rosa, já que aquele expõe que se destacam no método inquisitorial

(a) o caráter universal das denúncias, ou seja, não mais restritas à vítima ou aos seus familiares e interessados; (b) o sigilo da identidade do delator (noticiante); (c) a inexistência de separação entre as figuras de acusador e julgador, sendo lícito ao magistrado realizar a imputação, produzir a prova e decidir o caso; (d) o sistema tarifado de provas, com a conseqüente graduação da culpabilidade, na qual a confissão recebe valor supremo (regina probatio); e (e) a autorização irrestrita para o uso da tortura como mecanismo idôneo de obtenção da verdade. (CARVALHO, 2005, p. 59)

A incessante meta de alcançar a verdade na estrutura Inquisitorial admitiu as maiores barbáries "processuais" conhecidas ao longo dos tempos. A valorização da confissão como a rainha das provas permitiu que em sua busca ocorresse a tortura como método lícito e científico.

Aury Lopes Júnior também entende que essa busca pela verdade é o que determinou a crueldade do sistema, quando diz: a lógica inquisitorial está centrada na verdade absoluta e, nessa estrutura, a heresia é o maior perigo, pois atacava o maior núcleo fundante do sistema. Fora dele não havia salvação. Isso autoriza o "combate a qualquer custo" da heresia e do herege, legitimando até a mesmo a tortura e a crueldade nela empregada (LOPES JÚNIOR, 2006, p. 169).

As regras para a utilização do "tormento", como também é chamada a tortura, estão tratadas no Manual dos Inquisidores. É evidenciado que para a aplicação do tormento o réu reputado como herege deveria o mesmo ter cometido "um testemunho de vista, um mau comportamento em matéria de fé, um indício veemente, uma só não basta, duas são necessárias e bastantes para dar tormento" (EYMERICO, 2001, p. 46).

Identifica-se também a possibilidade do uso da tortura quando

após ter sido apurado, sem frutos, todos os demais meios para se averiguar a verdade, porque, muitas vezes, basta para fazer com que confesse o réu apenas os bons modos, a manha, suas próprias reflexões, as exortações de sujeito bem intencionados e o desconforto do cárcere. (EYMERICO, 2001, p. 47)

É fato tão notório que a confissão tinha um poder predominante sobre os outros métodos probatórios que Eymerico, no Manual dos Inquisidores, identifica que "quando confessa um acusado o seu delito pelo qual foi preso pela inquisição, é diligência inútil outorgar- Ihe defesa, sem que obste que nos demais tribunais não seja bastante a confissão do réu, quando não há corpo delito formal" (EYMERICO, 2001, p. 39).

No tocante ao crime religioso é explanado também que "em se tratando de heresia, a confissão do réu basta por si só para condená-lo, porque como a heresia é um delito da alma, muitas vezes não pode haver dela outra prova que não a confissão do acusado" (EYMERICO, 2001, p. 39).

Destarte, percebe-se que a tortura era utilizada como mecanismo para "arrancar" a verdade na forma em que se desejava. A utilização de tal "instrumento" traduz uma perspectiva própria do Sistema Inquisitorial, sendo esta a percepção de que o poder determinava não somente a verdade, mas também como obtê-la, identificando-se aí o exercício do poder, na compreensão pura do que ele significa.

\section{SISTEMA INQUISITORIAL NO BRASIL}

O Sistema Inquisitorial foi um processo de mudança de mentalidade e construção dogmática basicamente originado na Europa, no entanto, trata-se de um processo exclusivamente Ocidental. Estabeleceu-se o mesmo de forma mais fortificada e duradoura na Espanha e em Portugal e teve a sua consolidação como um sistema processual em meio a uma estrutura jurídica e de uma finalidade penal. 
A estrutura referida acima se tratava da organização do Tribunal do Santo Ofício da Inquisição, posteriormente reconhecido apenas como Inquisição, e a finalidade do mesmo tratava-se do fim punitivo deste sistema representado pela aplicação de uma pena ao condenado.

O processo histórico pelo qual passou Portugal está vinculado com o fortalecimento da Nobreza e da vinculação desta com o Clero. A Expansão Marítima, a Colonização e exploração do continente americano, a exploração do continente africano e as demais repercussões históricas da modernidade trazem consigo o movimento jurídico e religioso da Inquisição.

O Brasil teve como vertente primária, aos olhos de Portugal, a perspectiva exclusiva de Colônia de Exploração. A partir de tal consciência era de suma importância para os Estados colonizadores que se extraíssem todas as matérias primas e fontes de riqueza que fosse possível da localidade, de forma que não houvesse qualquer preocupação mais precisa com aqueles que faziam tal extração.

Porém, as descobertas provenientes da exploração (e outros diversos acontecimentos históricos) traçaram para o "Brasil" um caminho distinto daquele inicialmente planejado à Colônia. Descobriu-se nas terras americanas a solução para alguns problemas sociais dos povos europeus, e foi nela, principalmente, que Portugal encontrou a possibilidade de enriquecer.

Ao focar nesta visão, a Metrópole observou que para o funcionamento da Colônia seria necessário estabelecer hierarquias e para que se consolidasse o poder e o domínio territorial seria necessário colonizá-la. Assim, a colonização requereu da Metrópole um cuidado com a população que se encontrava na Colônia e o devido controle desta.

O exercício de poder vem, então, mediante as primeiras manifestações da presença da Inquisição no Novo Mundo: as visitações.

A estrutura do Sistema Inquisitorial era formada pela existência de alguns Tribunais fisicamente instituídos em "Lisboa, Coimbra, Évora, Lamego, Tomar e Porto" (CIDADE, 2001 , p. 22), todos devidamente estabelecidos em Portugal. Outros locais tiveram estruturas inquisitoriais, entretanto, é mais relevante ao objetivo deste trabalho o reconhecimento da Inquisição em Portugal, já que foi ela a responsável pela implementação desta forma processual no Brasil (CIDADE, 2001, p. 22).

As Visitações foram o resultado de um processo de "sedentarização" da Justiça tanto no âmbito do poder clerical quanto do poder monárquico. As visitações religiosas consistiam numa

inspeção periódica, que, por determinação do ConseIho Geral do Santo Oficio, realizava um delegado seu para inquirir do estado das consciências em relação à pureza da fé e dos costumes. Um patrulha de vigilância. Oferecia misericórdia aos confitentes, e, ao mesmo tempo, sob ameaça, incitava os denunciantes.
Um levantamento geral do momento dos espíritos. Uma operação de coleta de material para alimentação da máquina da Justiça do Santo Ofício (SIQUEIRA, 1978, p. 183)

As terras brasílicas não se viram livres das Visitas do Tribunal do Santo Ofício (OLIVEIRA, 2001, p. 1). Entendem alguns historiadores que a escolha das localizações pelas quais passariam as visitações estava conexa com a importância econômica da região.

A motivação real do surgimento das Visitações foi proveniente de um movimento de compreensão sobre a realidade das Colônias. É percebida por Portugal a necessidade do controle sobre as pessoas e sobre a realidade encontrada em suas terras distantes, e vê-se dentro da composição do Tribunal do Santo Ofício, que a figura apropriada para tal repressão seria os Visitadores.

A composição orgânica da Inquisição se dava através de uma organização judiciária, inicialmente composta pelas figuras dos

Inquisidores, dos Notários, do Meirinho, de outros funcionários de uma importância mais técnica como os médicos e ainda os guardas e porteiros para garantir a segurança e também os Visitadores das Naus (CIDADE, 2001, p. 22). então

A figura dos Visitadores das Naus surge

devido ao desenvolvimento do comércio e da navegação. Em virtude desses fatores, multiplicavam-se os contatos com outros povos e a criação dessa função deve-se à consciência de perigo que o contato com os estrangeiros representava em relação à integridade da fé católica (CIDADE, 2001, p. 25).

É ele um antecessor da figura do Visitador das Colônias. O Visitador de Naus era o responsável pela investigação de uma navegação quando esta, ao voltar dos mares, aportava nas cidades portuguesas, sendo necessário para o Tribunal do Santo Ofício que se averiguasse a origem e as intenções daquelas novas pessoas que chegavam às terras de Portugal.

O desenvolvimento das navegações e do processo migratório e colonizador nas terras americanas criaram assim a necessidade desta verificação também sobre as intenções e sobre a origem daqueles que fossem habitar as novas terras portuguesas. Assemelhando-se em função e finalidade criam-se os Visitadores das Colônias, os quais serão responsáveis pela averiguação do "caráter e da conduta" daqueles que lá se instalassem.

As Visitações então ocorreram como um reflexo do desenvolvimento de Portugal e de suas conquistas. Assim, no que se refere à localização destas Visitações percebe-se esse mesmo reflexo, já que a razão da escolha dos locais onde estas iriam ocorrer também derivava do desenvolvimento da região em importância econômica e política perante a Metrópole.

Oliveira, baseando-se na autora Anita Novinsky, entende que 
o envio da visitação está ligada à vigilância das terras mais prósperas da colônia - sobretudo as capitanias da Bahia e Pernambuco - bem como a manutenção da ordem e da fé católicas,ou seja,para Novinsky a instalação das visitas do Santo ofício ao Brasil estão intimamente ligadas a uma real necessidade de uma vigilância ativa sobre as áreas de maior prosperidade colonial, onde se encontrava uma grande parcela dos cristãos novos saídos do reino (OLIVEIRA, 2001, p. $1)$.

Todavia, há autores que entendem que as localizações não estão relacionadas diretamente com o desenvolvimento econômico, mas sim com o crescimento populacional e a necessidade de se cristianizar tais indivíduos, pois o objetivo maior das Visitações era de encontrar cristãos-novos e integrar o Brasil ao mundo cristão (OLIVEIRA, 2001, p. 2).

As primeiras visitações ocorreram inicialmente em Pernambuco e na Bahia entre os anos de 1591 - 1595. O objetivo principal dos Visitadores em terras brasílicas era o de encontrar principalmente práticas judias provenientes dos cristãos-novos.

Os cristãos-novos eram um grupo de judeus que foram compulsoriamente convertidos em novos cristãos em consequência do

decreto real em 1496-7 e que viveriam, a partir de 1536, constantemente ameaçados de prisão e confisco pelo Tribunal do Santo Oficio da Inquisição, cujo mote principal era a punição dos cristãos-novos "judaizantes", ou seja, que continuavam a praticar ocultamente o judaísmo. (VIEIRA, 1957, p. 45-47)

Os cristãos-novos estiveram muito presentes nas Colônias portuguesas, principalmente nas encontradas no continente americano, pois ao fugirem da Inquisição muito estabelecida fortemente no Velho Mundo, encontraram nas terras ultramar a possibilidade de praticarem ocultamente as suas filosofias religiosas e de buscarem uma ascensão econômica através do domínio de terras (VIEIRA, 1957, p. 45-47).

Outra finalidade evidente da vinda das Visitações, além do combate das práticas de heresias, foi a de extinguir os crimes contra a moral. Os focos de pesquisa do Santo Ofício, no tocante às práticas imorais, foram sobre os atos homossexuais e sodomíticos.

Destarte, sobre as condutas homossexuais entendia-se que

estes tipos de práticas seriam recorrentes entre as sociedades indígenas; tanto de homens, em que alguns efeminados viviam entre as mulheres, como de índias que viviam entre os homens, casavam e guerreavam, fazendo questão de serem tomadas por machos. O primeiro caso a ser registrado pela Inquisição aqui no Brasil foi o do negro Francisco denunciado em 1591, na Bahia. Praticante do "pecado nefando" foi denunciado por se recusar a vestir roupas de homem. Na própria Península Ibérica este tipo de delito seria comum entre os membros da Igreja, chegando a ser conhecido como o "vício dos clérigos" (OLIVEIRA, 2001, p. 4).

A segunda Visitação ao nordeste brasileiro ocorreu em 1618, onde Visitadores do Santo Ofício percorreram novamente as mesmas regiões buscando os mesmos delitos e as mesmas práticas hereges. Ocorreram também Visitações em 1627 ao Nordeste, 1606 e 1627 ao Sul e em 1763 ao Pará.

Numa perspectiva geral pode-se entender que as Visitações do Santo Ofício vieram com o propósito de controle, conforme entende Oliveira, que percebe que

\begin{abstract}
a visita do Santo Oficio é a tentativa de controle da ordem e vigilância acerca dos "desvios" da fé católica, em um novo lugar e em uma nova realidade seria nada mais natural o surgimento de outros tipos de "desvios", de práticas ditas "erradas", de sincretismos e de adaptações de elementos da fé oficial às realidades peculiares existentes na colônia. Vemos nas Santidades a mistura da hierarquia católica a elementos da religiosidade Tupinambá, percebemos também nos casos de práticas criptojudaicas a tentativa de conservação e manutenção da religiosidade outrora praticada por antepassados. A lógica Inquisitorial consistia em seguir valores e atitudes ditas corretas, desvalorizando o diferente, geralmente visto como errado e desviante. Nos caminhos trilhados pela Inquisição em terras basílicas, é vista uma realidade nova e multifacetada, através de um centro de significado, caracterizado na figura da fé oficial, percebemos o controle das práticas dos colonos através da intolerância da fé, misturada com a fé da intolerância (OLIVEIRA, 2001, p. 4 -5).
\end{abstract}

Assim, a partir da premissa da Inquisição, no Brasil e no mundo, e de identificação da normalidade, vê-se uma construção do outro como punível. A exclusão e determinação de certas práticas e condutas como aceitáveis à sociedade passa a ser vista como situações formadoras do conceito de Criminologia, a qual vai coexistir ao longo da história brasileira com o conceito de Sistema Penal, mais propriamente aqui identificado pelo Inquisitorial.

A busca incessante pela condenação do diferente numa sociedade tão mestiça como a que existia nos anos da modernidade no Novo Mundo caracteriza a relação de segregação que vai resultar dessa mentalidade construída sob a influência da vigilância da Inquisição.

\section{A CRIMINOLOGIA E O SISTEMA INQUISITORIAL}

Aparentemente pode ser difícil identificar a relação que há entre o Sistema Inquisitorial e o estudo da Criminologia. Ao se deparar, contudo, com a relação de indivíduos e acusados no processo penal, começa-se a traçar uma conexão entre o estudo do crime e as relações de poder que determinam quem é o criminoso.

Faz-se presente uma relação que permeia os dois conceitos existentes nos dois momentos: ambos possuem um objetivo segregador. Khaled Júnior (2010, p. 110) discorre sobre este objetivo expondo que

apesar da diferença aparente de foco, um objetivo comum aproxima os dois saberes: a tentativa deliberada de erradicar a diferença e anular o outro. A pretensão de homogeneização do corpo social efetivamente permite a percepção de continuidade entre uma prática dogmático-religiosa e a constituição de 
um campo de saber científico. De fato, a própria elaboração de uma Criminologia oitocentista que tinha - por excelência - o homem como objeto, se vale dos pressupostos inquisitórios em alguma medida, ainda que de forma velada. O que muda, essencialmente, é o padrão desejável de indivíduo e o que é considerado uma ameaça para a funcionalidade do sistema e da estrutura de poder dominante.

A Inquisição focava sua atenção nos hereges, e como observado acima, a Igreja, como órgão regulador da Santa Inquisição, segregava aqueles que pensavam ou criam de forma diferente daquilo que era imposto. Verifica-se então a partir do conceito de herege o surgimento da identificação do outro como "anormal", como perigoso, como aquele que é diferente do desejado, traços que serão determinantes para o conceito contemporâneo de criminoso.

\section{Como expõe Foucault}

Toda a penalidade do século XIX passa a ser um controle, não tanto sobre se o que fizeram os indivíduos está em conformidade ou não com a lei, mas ao nível do que podem fazer, do que são capazes de fazer, do que estão sujeitos a fazer, do que estão na iminência de fazer.

Assim, a grande noção da criminologia e da penalidade em fins do século XIX foi a escandalosa noção, em termos de teoria penal, de periculosidade. A noção de periculosidade significa que o indivíduo deve ser considerado pela sociedade ao nível de seus atos; não ao nível das infrações efetivas a uma lei efetiva, mas das virtualidades de comportamentos que elas representam (FOUCAULT, 2003, p. 85)

A partir do conceito de Criminologia explorado por Foucault sobre a construção do sujeito criminoso e sua periculosidade, pode-se abordar, sem o receio de se cometer anacronismo, que a figura do sujeito "perigoso" está presente na construção do conceito de Herege, palavra importantíssima dentro do Sistema Inquisitorial.

Salo de Carvalho, ao trabalhar com as perspectivas de criminologia diante da Inquisição, aborda que o livro Malleus Maleficarum (Martelo das feiticeiras) iniciou a formação do conceito de criminologia. O autor evidencia que Heinrich Kramer e James Sprenger, escritores desse livro, constroem ao longo do texto uma nova percepção, a qual aborda o crime através do criminoso, ao identificar certos indivíduos como propensos à prática de delitos. Explana Salo de Carvalho que

no âmbito criminológico, estabelece (a Inquisição) discurso etiológico plurifatorial baseado na potencialização da gravidade do delito, na inferioridade do homo criminalis (dos homens infames, dos degenerados sexualmente e das mulheres) e na predestinação ao crime. Em relação ao discurso penal, submete-o de forma extremada aos modelos de autor - inaugurando a lógica do direito penal da periculosidade -, estabelecendo amplo conjunto de signos que permitem identificar o crime no criminoso (CARVALHO, 2005, p. 64)

No contexto contemporâneo da criminologia percebem-se estudiosos que visam a identificar no movimento social exatamente a relação entre o crime e o criminoso, observando mais especificamente a periculosidade deste.

Como resposta a esse movimento conhecido como criminologia vê-se acadêmicos de diversas áreas, como antropólogos, médicos, juristas que formulam, no fim do século XIX uma tese de dosimetria da pena, na qual a pena a ser estipulada ao criminoso deveria ser medida proporcionalmente com a sua "temibilidade" (DARMON, 1991, p. 143), termo definido por Darmon como "a quantidade de mal que podemos temer da parte do criminoso em razão da sua pervesidade" (DARMON, 1991, p. 143).

A Criminologia Clássica, trabalhada principalmente por Beccaria ao longo do século XVIII, rompe com as tradições medievais. Esta nova perspectiva do crime aborda uma proposta que desassocia a pena dos castigos corpóreos e analisa o crime sob a ótica do livre arbítrio, no qual o homem tinha condições e discernimento necessários para decidir sobre a prática do delito. Era também característica dessa Escola criminológica ter como foco de estudo a pena em si e as suas consequências sociais (BECCARIA, 1996).

Contudo, a partir do sec. XIX houve uma modificação nas reflexões sobre o fato ilícito, tornando-se o centro das atenções novamente o criminoso e não mais a punibilidade até então presente na Escola Clássica. Com a abordagem do criminoso e dos conceitos que permeavam suas condutas, percebe-se um retorno às formas inquisitoriais de se identificar o delinquente.

Esta "nova" proposta no século XIX de periculosidade e de análise do infrator é proveniente principalmente de Cesare Lombroso, considerado precursor da Criminologia positivista e ditador de personalidades essencialmente "normais" e "morais".

O citado autor fundou uma nova perspectiva para a criminalidade, afastando o crime da lente objetiva e colocando sob esta o criminoso, os quais eram interpretados sobre três fatores "phisicos, anthropologicos e sociais" (SCHWARCZ, 2005, p. 166), os quais distinguiam o sujeito normal do anormal. Para esta interpretação

O tipo físico do criminoso era tão previsível que seria possível delimitá-lo de forma objetiva. Lombroso, por exemplo, criou uma minuciosa tabela, subdividida em: "elementos anathomicos" (assimetria cranial e facial, região occipital predominante sobre a frontal, fortes arcadas superciliares e mandíbulas além do prognatismo); "elementos physiologicos" (tato, embotado, olfato e paladar obtusos, visão e audição ora fracas ora fortes, falta de atividade e de inibição); e "elementos sociológicos" (existência de tatuagens pelo corpo) (SCHWARCZ, 2005, p. 166).

O crime feminino também foi bastante abordado por Lombroso e Ferrero, e por eles é visto "como uma dupla exceção", pois a mulher se torna um monstro (VENERA, 2003, p. 57). Nessa perspectiva de dupla exceção observa- 
-se que a transgressão à ordem pela mulher é vista como um crime que "vem duplamente: por estar (a mulher) saindo da ordem e por ser uma mulher saindo da ordem, e por ser um sujeito biologicamente imprevisto para ser criminoso" (VENERA, 2003, p. 57).

Para os já acima citados autores o senso de justiça da mulher também não era confiável, pois

Relativamente a nós [homens] a mulher é um ser imoral. Ela está sempre de um e de outro lado da justiça; ela não tem nenhuma inclinação para o equilíbrio dos deveres e dos direitos que fazem a preocupação do homem; sua consciência é antijurídica como seu espírito é antifilosófico. Sua inferioridade moral junta-se a sua inferioridade física e intelectual como conseqüência necessária (SOIHET, 1989, p. 112).

Mesmo quando os autores abordavam a "normalidade" feminina não se tratava de algo benéfico, mas sim, como se a mulher, por natureza, fosse diferente pelo simples fato de não ser homem. Lombroso assim descrevia:

A mulher normal, em resumo, tem muitas características que a aproximam do selvagem e da criança e em conseqüência do criminoso (irascibilidade, vingança, ciúme, vaidade) e outras diametralmente opostas que neutralizam as primeiras, mas que a impedem entretanto de se comparar ao homem no equilíbrio entre direitos e deveres, o egoísmo e o altruísmo que é o termo supremo da evolução moral (SOIHET, 1989, p. 112).

Como modelo estrutural para a formação do conceito de condutas normais, se utilizava o termo padronizador "homem médio" (VENERA, 2003, p. 42), sendo que este homem não cometeria homicídios, não roubaria, não praticaria infrações, pois as práticas que extrapolassem o limite das imposições destinadas ao "homem médio", tratar-se-iam de condutas de "pura infração ou anormalidade" (VENERA, 2003, p. 42).

Assim, é a partir destes conceitos formulados por Lombroso que podemos identificar a relação existente entre a Criminologia nos padrões da contemporaneidade, com a perspectiva de crime e criminosos estabelecida pelo Sistema Inquisitorial.

No Sistema Inquisitorial tem-se como objeto máximo de fragilidade diante da possibilidade de cometer uma heresia a mulher. Esse conceito volta, como demonstrado, predominando no discurso dos juristas criminológicos do século XIX.

Destarte, visa-se a percepção em ambos os momentos de uma segregação de certos grupos e certos indivíduos, identificando aí a relação que se tem da criminologia positivista, que até hoje vige veladamente sobre o Judiciário quando a relaciona com o Sistema Inquisitorial de análise do processo, o qual também vige sobre o Judiciário, entretanto, não tão veladamente assim.

\section{O PAPEL DO JUIZ INQUISIDOR}

Um sujeito muito singular no sistema inquisitorial é o Juiz. A sua função como julgador de conflitos identifica uma das características mais próprias desse sistema: a unificação do acusador e do julgador em uma única pessoa.

A persecução jurídica vem configurada na pessoa do juiz, assim como a própria resolução do conflito. Tal fato traz, como já foi evidenciado, a razão determinante de ser do Sistema Inquisitorial. Devido a esta junção de funções é possível observar a inexistência de garantias protetoras ao acusado, tais como a ampla defesa, o contraditório e a presunção de inocência.

Esta aglomeração de funções num único indivíduo foi uma das razões para ocorrência reiterada das torturas e sua intensidade, haja vista a possibilidade de se buscar a verdade a qualquer custo, não havendo, assim, limites processuais para a obtenção de provas favoráveis à condenação. A partir dessa gestão probatória percebe-se o poder real de controle do processo nas mãos no julgador proveniente dessa união que havia na figura do magistrado.

Para Jacinto Coutinho, o Sistema Inquisitorial tem como característica principal a gestão das provas. O autor identifica que

a característica fundamental do sistema inquisitório,
na verdade, está na gestão da prova, confiada es-
sencialmente ao magistrado que, em geral, no mo-
delo em análise, recolhe-a secretamente, sendo que
"a vantagem (aparente) de uma tal estrutura resi-
diria em que o juiz poderia mais fácil e amplamente
informar-se sobre a verdade dos factos - de todos os
fatos penalmente relevantes, mesmo que não con-
tidos na 'acusação' - , dado o seu domínio único e
omnipotente do processo em qualquer das suas fases
(COUTINHO, 2001, p. 24).

O Manual do Inquisidor é um livro escrito por Nicolau Eymerico, no século XIV, cuja função era determinar e identificar as práticas da Santa Inquisição com intuito de direcionar os inquisidores ao caminho mais eficiente de "livrar o mundo dos hereges". É neste manual identificado qual o papel do juiz na perseguição dos acusados e quais os procedimentos que por ele deveriam ser adotados para que se "conquistasse" o maior número de confissões e, consequentemente, de condenações.

O juiz, nos termos do livro exposto, deveria, para obter a "verdade real" dos fatos, fazer o papel de interrogador e através de 06 formas distintas buscar a confissão do réu sem a necessidade dos suplícios (EYMERICO, 2001 , p. 36). Estas formas eram identificadas por Eymerico (2001, p. 36) como "artes e manhas que usarão os inquisidores para saber a verdade pela boca dos hereges, gratiose, sem usar mão do potro ".

Entre estas formas pode-se citar o fingimento do inquisidor em se tratar ele mesmo de um herege para obter a confiança do acusado, ou a multiplicidade de interrogatórios e per- 
guntas até levar o réu à exaustão ou ameaçá-lo de mantê-lo preso por tempo indeterminado (EYMERICO, 2001, p. 30 - 38).

Fica assim evidenciado que o juiz "atua como parte, investiga, dirige, acusa e julga" (LOPES JUNIOR, 2006, 168) e que no decorrer do processo "ele e os demais oficiais do tribunal assumiam a investigação dos crimes e determinavam a culpabilidade ou não do réu" (SANCHES, 2010, p. 12), o que determinava exatamente o que hoje chamamos de cerceamento de defesa.

Outra perspectiva do cerceamento de defesa no processo inquisitório está no segredo que envolvia o procedimento, tanto ao público quanto ao acusado. Foucault discorre que

todo o processo criminal, até a sentença, permanecia secreto: ou seja, opaco não só para o público, mas para o próprio acusado. O processo se desenrolava sem ele, ou pelo menos sem que ele pudesse conhecer a acusação, as imputações, os depoimentos, as provas (...) era impossível ao acusado ter acesso às peças do processo, impossível conhecer a identidade dos denunciadores, impossível saber o sentido dos depoimentos antes de recusar as testemunhas, impossível fazer valer, até os últimos momentos do processo, os fatos justificativos, impossível ter um advogado, seja para verificar a regularidade do processo, seja para participar da defesa (FOUCAULT, 1991, p. 35).

Quanto à figura do advogado é também relevante identificar que o mesmo deveria ser indicado pelo próprio inquisidor do processo e que não haveria qualquer garantia de paridade entre os sujeitos processuais.

\section{Eymerico discorre que}

O advogado há de ser um homem justo, douto e zelador da fé. Nomeia-o o inquisidor e Ihe toma juramento de defender o réu conforme a verdade e o direito, e de guardar como inviolável o quanto vir e ouvir. Será seu principal esmero exortar seu cliente a declarar a verdade e pedir perdão do seu delito se for culpado. Responderá o acusado de palavra ou por escrito, de acordo com o seu advogado e se passará a resposta ao fiscal do Santo Oficio. O preso não se comunicará com o advogado sem a presença do inquisidor (EYMERICO, 2001, p. 36).

Percebe-se assim que não há qualquer chance para o acusado neste sistema, este fica à margem do poder discricionário do juiz e das imposições da Inquisição, visto que toda a linha "processual" é voltada para a condenação.

Fica também evidenciado que o personagem do magistrado no sistema inquisitório trata-se da figura principal, haja vista sua importância perante o processo da Inquisição.

Ao agregar funções e ser o sujeito que dita todas as regras do jogo processual, o juiz rege o ritmo do processo e decide de antemão a culpabilidade do acusado, passando desta convicção para busca das provas, o que caracteriza aí o manuseio probatório da forma que convém ao juiz (LOPES JÚNIOR, 2006, p. 168).

Outra perspectiva importante deste sujeito é a subjetividade com que o magistrado vem a trabalhar no sistema inquisitório, já que fica à sua disposição a possibilidade de decidir da forma que achar mais conveniente sobre todos os fatos presentes no processo.

O livre convencimento do juiz permitia desde então que houvesse um caráter discricionário e subjetivo quanto aos seus sentimentos e "intuições" em relação ao acusado, demonstrando-se aí mais um artifício de poder atribuído ao magistrado neste sistema (LOPES JÚNIOR, 2006, p. 168).

Pode-se assim concluir que o sistema inquisitorial em si é uma máquina de poder, desde a construção do inquérito, da seleção dos acusados até a determinação do juiz sobre a culpabilidade do mesmo e da discricionariedade com que o magistrado trabalha na gestão das provas.

Vê-se na Inquisição a identificação do fim da Idade Média e do poder determinante que teve a Igreja neste período, entende-se nela a construção da mentalidade repressora que está até então agregada ao Sistema penal e ao processo penal. Percebe-se o quão relevante a figura do juiz é a partir do autoritarismo exercido por ele e quão vulnerável fica o réu quando se encontra sem qualquer garantia, diz-se então que o papel do juiz no Sistema Inquisitório é o de domínio completo sobre o processo e o seu procedimento.

\section{CONSIDERAÇÕES FINAIS}

A forma inquisitória é possível de ser identificada quando se demonstra a ausência dos direitos processuais do contraditório, de ampla defesa e da evidência absoluta da presunção de culpa do acusado, cabendo ao mesmo o ônus probatório quanto a sua inocência. Outras características atribuídas ao sistema inquisitorial são a tarifação das provas e a acusação de ofício, todavia, o ponto crucial para a sua identificação é a unificação dos poderes de julgar e acusar nas mãos dos magistrados. Os juízes inquisitoriais são aqueles que colhem as provas, efetivam a acusação e julgam o processo.

A mais significativa peculiaridade do sistema inquisitório fica a cargo da possibilidade da tortura como meio de alcançar a verdade processual. Ficou demonstrado, diante do exposto, por Eymerico que a prática de tormentos, além de ser algo inerente a esta forma processual, tratava-se de uma obrigação do inquisidor, já que eram tarefas suas a obtenção dos indícios probatórios para acusar o indivíduo e sua efetiva condenação.

O Sistema Inquisitorial é uma construção processual do ocidente surgido no Velho Mundo, entretanto, devido às Colonizações e ao processo expansionista dos países europeus, ele atingiu várias outras localidades, entre elas o Brasil.

Demonstra-se, então, a chegada da inquisição ao Brasil, identificando-a como resultado de um processo proveniente da necessidade 
que Portugal teve em controlar seus colonos e suas práticas.

Numa sociedade distante e sem os olhares diários do rei e da Santa Inquisição, Portugal percebeu que tal realidade possibilitava uma liberdade de conduta distinta da que a Metrópole vivia no século XVI e XVII, o que permitia práticas religiosas e sexuais que eram abolidas em terras portuguesas. Para controlar então o que ocorria na Colônia, o Santo Ofício foi mandado ao Brasil para identificar e punir tais comportamentos inaceitáveis, segregando assim certos grupos de indivíduos e seus costumes.

Como resposta a essa segregação, ficou demonstrada a relação do Sistema Inquisitorial com a construção da Criminologia positivista surgida no final do século XVII. Na identificação da normalidade, vê-se uma construção do outro como punível. A exclusão e determinação de certas práticas e condutas como aceitáveis à sociedade passa a ser vista como situações formadoras do conceito de Criminologia

O surgimento deste discurso de indivíduos diferentes e anormais no Brasil deve-se principalmente à divulgação da teoria da criminologia lombrosiana efetuada pela Faculdade de Direito de Recife através das suas publicações acadêmicas, que tinham como foco principal compreender o crime através da pessoa do criminoso e de suas características de periculosidade. Foi, assim, identificado por esta abordagem criminológica que em determinadas pessoas a criminalidade era produto de atributos naturais derivados de uma má-formação biológica destes indivíduos, e era diante de um determinismo biológico que a presente teoria identificava o porquê das transgressões.

Destarte, evidencia-se a figura principal dentro da realidade inquisitorial, o juiz inquisidor. As atribuições funcionais e as práticas inerentes a esse personagem são analisadas como a razão que constitui em si o processo inquisitório.

A junção das funções de acusar e julgar, a possibilidade das torturas para a obtenção da "verdade real" e a decisão com ausência de quaisquer fundamentações identificavam exatamente a liberdade dos juízes inquisidores, possibilitando assim que estes praticassem atos absurdos como meio de obter condenações, caracterizando desta forma a realidade do Sistema processual inquisitório.

\section{REFERÊNCIAS}

BECCARIA, Cesare. Dos delitos e das penas. 11.ed. São Paulo: Ed. Hemus, 1996.

CARVALHO, Salo de. Anti manual de criminologia. Rio de Janeiro: Ed. Lúmen Júris, 2008. 228p.
- Revisita à desconstrução do modelo

jurídico inquistorial. 2005. Disponível

em: <http://www.buscalegis.ufsc.br/

revistas/index.php/buscalegis/article/ viewArticle/32639>. Acesso em: 11 mai 2010.

CIDADE, Rodrigo Ramos Amaral. Direito e inquisição: o processo funcional do Tribunal do Santo Ofício. Curitiba: Juruá, 2001. 102p.

COUTINHO, Jacinto Nelson de Miranda. (Coord.). Crítica à teoria geral do direito processual penal. Rio de Janeiro: Renovar, 2001. 292p.

As reformas parciais do CPP

e a gestão da prova: segue o Princípio Inquisitivo., Boletim no 188, de jul./2008. Artigo publicado no IBCCrim

DARMON, Pierre. Médicos e assassinos na "Belle Époque": a medicalização do crime. Rio de Janeiro: Paz e Terra, 1991.

EYMERICO, Nicolau. Manual da inquisição. Curitiba: Juruá, 2001. 154p.

FOUCAULT, Michel. A ordem do discurso. São Paulo: Ed. Loyola, 1996.

. Vigiar e punir: nascimento da prisão. Petrópolis: Vozes, 2003.

KHALED JÚNIOR, Salah H. A gênese do saber criminológico oitocentista. Disponível em: <http://www.seer.furg.br/ojs/index.php/ juris/article/viewFile/934/380 >. Acesso em: 12 maio 2010

LOPES JÚNIOR, Aury. Direito processual penal e sua conformidade constitucional. 3.ed. Rio de Janeiro: Ed. Lúmen Júris, 2009. 680 p. . Introdução crítica ao processo penal. Rio de Janeiro: Ed. Lúmen Júris, 2006. 315p.

SANCHES, Samyra; NASPOLINI, H D. F.. Aspectos Históricos, Políticos e Jurídicos da Inquisição. In: WOLKMER, Antonio Carlos. (Org.). Fundamentos de história do direito. 5.ed.Belo Horizonte: Del Rey, 2010, v. , p. 239-254. 
OLIVEIRA, Halyson Rodrygo Silva de. O Tribunal do Santo Ofício: primeira visita do Tribunal às partes do Brasil, Bahia e Pernambuco (1591-1595). Disponível em: <http://www.cchla.ufrn.br/humanidades/ ARTIGOS/GT26/>. Acesso em: 12 mai 2010.

ROSA, Alexandre Morais da. Decisão penal: a bricolage de significantes. Rio de Janeiro: Lúmen Júris, 2006.

SCHWARCZ, Lilia Moritz. O espetáculo das raças: cientistas, instituições e questão racial no Brasil. São Paulo: Companhia das Letras, 2005.

SIQUEIRA, Sonia A. A inquisição portuguesa e a sociedade colonial. São Paulo: Editora Ática, 1978. 398p.

SOIHET, Rachel. Condição feminina e formas de violência: mulheres pobres e ordem urbana (1890-1920). Rio de Janeiro: Editora Forense Universitária, 1989.

VENERA, Raquel Alvarenga Sena. Cortinas de Ferro: quando o estereótipo é a lei e a transgressão feminina - processos crime de mulheres, em Itajaí - décadas de 1960 a 1990. Dissertação (Mestrado em História) - Universidade Federal de Santa Catarina, Florianópolis, 2003.

VIEIRA, Antonio. Defesa perante o Tribunal do Santo Ofício. Salvador: Livraria Progresso Editora, 1957. 342p.

WOLKMER, Antonio Carlos. (Org.).

Fundamentos de História do Direito. Belo Horizonte: Ed. Del Rey, 2003. 432 p. 